\title{
Calcium Intake And Body Mass Index (BMI) On Bone Density

\author{
$1^{\text {st }}$ Yunita Nazarena \\ Nutrition Department \\ Poltekkes Kemenkes Palembang \\ Palembang, Indonesia \\ yunitanazarena@yahoo.co.id
}

\author{
$2^{\text {nd }}$ Terati \\ Nutrition Department \\ Poltekkes Kemenkes Palembang \\ Palembang, Indonesia \\ terati_idris@yahoo.co.id
}

Corresponding author: yunitanazarena@yahoo.co.id

\begin{abstract}
Background: Osteoporosis is a disease characterized by reduced bone mass (density) and changes in the micro-architecture of bone tissue so that bone strength decreases and bone fragility increases (Menkes RI, 2008). Calcium intake is one of the determining factors in bone mass formation and has an effect on bone density (Setyawati et.al, 2013; Tusmantoyo et. al, 2014). The low BMI is related to the low achievement of peak bone mass and high bone mass loss (Ensrud et al, 2007). Objective: To analyze the relationship of calcium intake and Body Mass Index (BMI) to bone density Method: An epidemiological study that is observational analytic using a cross sectional study design. Independent variables: Calcium intake and Body Mass Index (BMI), dependent variable: Bone Density.Results: There was a significant correlation of respondents' calcium intake with bone mineral density $(p=0.029)$. Respondents with less calcium intake $(<80 \%$ AKG $)$ risk 3,877 times experiencing abnormal bone mineral density (DMT) compared with respondents with good calcium intake $(\geq$ $80 \%$ AKG). There was no significant relationship of body mass index (BMI) of respondents with bone mineral density $(p=0.309)$. Conclusions: There was a significant relationship between respondents' calcium intake and bone mineral density. Calcium intake is a risk factor for low bone density.
\end{abstract}

Keywords: osteoporosis; calcium intake; body mass index; bone density; young girl

\section{INTRODUCTION}

Osteoporosis is a disease characterized by reduced bone mass (density) and changes in the microarchitecture of bone tissue resulting in decreased bone strength and increased bone fragility (Menkes, 2008). Statistically, osteoporosis is defined as a condition in which Bone Mineral Density (DMT) is below the reference value according to age or the standard deviation is below the reference average for young adults [1].

Osteoporosis is experienced by many women, but it does not rule out that it occurs in men. This is because men have a denser bone mass and the bone demineralization process in men is also slower than women. Based on the records of the National Osteoporosis Foundation, it was found that $80 \%$ of osteoporosis is found in women. Reabsorption and bone formation imbalances are most often caused by menopause in women [2] Density is a measure of bone density. Bone mineral density is a marker for bone fracture risk. If the bone mineral density value is normal, the risk of fracture and osteoporosis will be smaller [3]. Bone mass density (DMT) provides the largest contribution to bone strength [4].

Prevention of low bone density can be done by maximizing bone mass during peak growth. Peak bone mass can be reached before the age of 30 years, whereas age > 30-40 years of bone density is relatively stable and when the age $>40$ years the loss of bone mass is irreversible [5]. During adolescence, growth spurt occurs, namely peak growth in height (peak high velocity) and body weight (peak weight velocity) as well as peak bone mass (PBM) growth which causes nutritional needs to be higher than other periods of life. As much as $90 \%$ of peak bone growth occurs at the age of 18 years for women and 20 years for men, so this is the best time to invest in bone density [6] 
Low bone mass occurs due to failure of the bone to reach normal mass. This can occur due to lack of physical exercise, poor intake of vitamin $\mathrm{D}$ and calcium, late puberty, smoking and excessive alcohol consumption. Peak bone mass is reached at the early age of 20 years [7]. Adolescence is a determinant of health conditions so that if it is not controlled, consumption of food and drinks can be detrimental to future periods. Calcium intake is a determining factor in bone mass formation and affects bone density[8]. The habit of consuming food sources of calcium can provide adequate reserves of calcium which are needed for plant growth and bone formation, which is reflected in bone density and bone size including height [9]. Calcium absorption is very important during the growth period in achieving optimal bone mass. Optimal bone mass formation is achieved up to 35 years of age. If in young adulthood is not able to meet the needs of calcium, it will increase the risk of fracture in old age [10]. Therefore, calcium is the most important specific nutrient in achieving optimal peak bone mass, preventing and treating osteoporosis [11].

suggests that low BMI is associated with lower peak bone mass attainment and higher bone mass loss. The backbone as part of the spine has an important role in the human body. In addition to its function as a place for the muscles to attach, it is also a support so that the body can stand firmly and carry out activities. The density of the backbone needs serious attention in maintaining its health. If the density of the spine does not reach its peak during adolescence, at the time of old age will be susceptible to the risk of osteoporosis which causes bones to become brittle and the body looks bent. If this continues, the spine will break easily (fracture) [13].

Adolescence is the peak period for bone mass formation. The achievement of a peak in the formation of optimal bone mass that is maintained can prevent the possibility of osteoporosis in the future. Osteoporosis is experienced by women more than men. Therefore it is necessary to do research on bone density in adolescents, especially young women to prevent osteoporosis. This study aims to analyze the relationship between calcium intake and Body Mass Index (BMI) on bone density in high school students.

\section{METHODS}

This research is an analytic observational epidemiological study using a cross sectional study design. This research was conducted at one of the public high schools in Palembang, South Sumatra Province.The study population was all students of class
$\mathrm{XI}$ in highh school with inclusion criteria aged $\geq 17$ years, able to communicate with them, willing to be research subjects by signing informed consent and good condition.

The sample size used the Lemeshow formula [14]using the prevalence of osteopenia in adolescents in 2010 of $32.7 \%$, while to calculate the proportion of students in each class it was calculated using proportional stratified random sampling technique because of the heterogeneous population.

The data collected in the form of respondent characteristics data (name, date of birth, class, address) were taken through a questionnaire on the respondent's identity, anthropometric data (weight and height). Weight data was measured using a bath room scale with a capacity of $120 \mathrm{~kg}$ with a precision of $0.1 \mathrm{~kg}$. Height data were measured using a microtoise with a maximum capacity of $200 \mathrm{~cm}$ with accuracy of $0.1 \mathrm{~cm}$. The results of the data on body weight and height are then processed using the Body Mass Index (BMI) to see the nutritional status. Calcium intake data was performed using the semi quantitative food frequency questionnaire (FFQ) method to determine the subject's eating habits during the past month by filling in the column according to the frequency (frequency) of food consumption listed in the food frequency list. Bone density data was measured using bone densitometry, as well as secondary data (general description data, number and names of students highh school) obtained from the school. The data that has been collected is verified and entered into a computer then processed descriptively and presented in the form of a table. Relationship analysis was performed using the chisquare test.

\section{RESULTS}

\section{A. Characteristics of Research Subjects}

This research was conducted at high school with a total of 50 respondents. Most of the respondents came from the MIPA class as many as 34 respondents $(68 \%)$. and partly from the Social Studies class as many as 16 respondents (32\%). Most of the respondents involved in this study each received an allowance of $\leq \mathrm{Rp}$. $600,000 /$ month as many as 39 respondents (78\%) and> Rp. 600,000, - / month as many as 11 respondents $(22 \%)$. 
Table 1 Characteristics of Respondents According to Class of Specialization and Allowances

\begin{tabular}{lcc}
\hline \multirow{2}{*}{ Characteristics } & \multicolumn{2}{c}{ Number of Respondents } \\
\cline { 2 - 3 } & $\mathbf{n}$ & $\mathbf{\%}$ \\
\hline Specialization Class & 34 & 68 \\
MIPA & 16 & 32 \\
IPS & & \\
\hline Pocket money & 11 & 22 \\
$>\quad$ Rp 600.000,-/month & 39 & 78 \\
$\leq$ Rp 600.000,-/month & \\
\hline
\end{tabular}

\section{B. Calcium intake}

The results of continuous data analysis showed that the average calcium intake was $922.28 \pm 405,916 \mathrm{mg} /$ day with a minimum value of $147 \mathrm{mg} /$ day and a maximum value of $1714 \mathrm{mg} / \mathrm{day}$, then the data were grouped into two, namely good calcium intake if calcium intake was $\geq 80 \%$ RDA and less calcium intake if calcium intake $<80 \%$ RDA.

Table 2 Respondents Frequency Distribution According to Calcium Intake

\begin{tabular}{lll}
\hline \multirow{2}{*}{ Calsium Intake } & \multicolumn{2}{c}{ Number Of Responden } \\
\cline { 2 - 3 } & $\mathbf{n}$ & \% \\
\hline High & 19 & 38 \\
\hline Less & 31 & 62 \\
\hline Total & 50 & 100 \\
\hline
\end{tabular}

\section{Body Mass Index (BMI)}

The results of continuous data analysis obtained an average body mass index value of $21.93 \pm 4.112 \mathrm{~kg} /$ $\mathrm{m} 2$ with a minimum value of $16 \mathrm{~kg} / \mathrm{m} 2$ and a maximum value of $36 \mathrm{~kg} / \mathrm{m} 2$. The data is grouped into two, namely Normal Body Mass Index and Abnormal Body Mass Index.

Table 3 Respondents Frequency Distribution According to Body Mass Index (BMI)

\begin{tabular}{lll}
\hline Body Mass Index & $\mathrm{n}$ & $\%$ \\
\hline Normal & 31 & 62 \\
\hline Abnormal & 19 & 38 \\
\hline Total & 50 & 100 \\
\hline
\end{tabular}

\section{Bone Density}

Bone density is obtained by measuring the heel (calcaneus bone) using ultrasound bone densitometry brand Sonost 3000. Bone mineral density is normal if the measurement results listed on the instrument show a $\mathrm{T}$ score $>-1.0$. If the $\mathrm{T}$ score printed on the instrument is at -2.5 to -1.0 , this indicates a low bone mineral density (osteopenia) and if the $\mathrm{T}$ score on the instrument is $<-2.5$ it indicates the bone mineral density in osteoporosis. The results of the bone mineral density measurement are then classified as normal if the respondent's bone density falls into the normal and abnormal category if the respondent's bone density is included in the osteopenia or osteoporosis category.

Table 4 Respondents Frequency Distribution According to Bone Mineral Density

\begin{tabular}{cll}
\hline \multirow{2}{*}{ Bone Mineral Density } & \multicolumn{2}{l}{ Number of Respondents } \\
\cline { 2 - 3 } & $\mathrm{n}$ & $\%$ \\
\hline Normal & 27 & 54 \\
\hline Abnormal & 23 & 46 \\
\hline Total & 50 & 100 \\
\hline
\end{tabular}

\section{E. Relationship between Calcium Intake and Bone Mineral Density}

Calcium intake of respondents is the average amount of calcium intake from food and beverages as well as multivitamin calcium that is consumed using the help of a semi-quantitative food frequency questionnaire through interviews then analyzed and converted in one day the average calcium intake. Then it is classified as good if the calcium intake is $\geq 80 \%$ RDA and less if the intake is $<80 \%$ RDA.

Table 5 Distribution of Respondents by Calcium Intake and Bone Mineral Density

\begin{tabular}{|c|c|c|c|c|c|c|c|c|}
\hline \multirow{3}{*}{$\begin{array}{l}\text { Calsium } \\
\text { intake }\end{array}$} & \multicolumn{4}{|c|}{ Bone Mineral Density } & \multirow{2}{*}{\multicolumn{2}{|c|}{ Total }} & \multirow{3}{*}{$\begin{array}{c}\text { OR } \\
(95 \%\end{array}$} & \multirow{3}{*}{$\begin{array}{c}\mathrm{p} \\
\text { Value } \\
\end{array}$} \\
\hline & \multicolumn{2}{|c|}{ Normal } & \multicolumn{2}{|c|}{ Abnormal } & & & & \\
\hline & & $\%$ & $\mathrm{n}$ & $\%$ & $\mathrm{n}$ & $\%$ & & \\
\hline $\begin{array}{r}\text { Good } \\
\geq 80 \% \\
\text { AKG }\end{array}$ & 14 & 73.7 & 5 & 26.3 & 19 & 100 & 3.877 & \\
\hline $\begin{array}{l}\text { Less } \\
<80 \% \\
\text { AKG }\end{array}$ & 13 & 41.9 & 18 & 58.1 & 31 & & $\begin{array}{l}(1.12- \\
13.47)\end{array}$ & 0.029 \\
\hline Total & 27 & 100 & 23 & 100 & 50 & & & \\
\hline
\end{tabular}

From Table 5, it can be seen that there are $5(26.3 \%)$ respondents with good calcium intake ( $\geq 80 \%$ RDA) who have abnormal bone mineral density. Meanwhile, among respondents with less calcium intake $(<80 \%$ RDA) there were $18(58.1 \%)$ who had abnormal bone mineral density. Chi-square test results with a confidence level of $95 \%(\alpha=0.05)$ indicate that there is a significant relationship between respondents' calcium intake with normal bone mineral density and 
respondents with abnormal bone mineral density ( $\mathrm{p}=$ 0.029). Respondents with insufficient calcium intake ( $<80 \%$ RDA) had a risk of 3,877 times experiencing abnormal bone mineral density (DMT) compared to respondents with good calcium intake ( $\geq 80 \%$ RDA).

\section{F. Relationship between BMI and Bone Density}

Table 6 Distribution of Respondents by BMI and Bone Mineral Density

\begin{tabular}{|c|c|c|c|c|c|c|c|c|}
\hline & \multicolumn{4}{|c|}{ Bone MineralDensity } & & & \multirow{3}{*}{$\begin{array}{l}\text { OR } \\
(95 \% \\
\mathrm{CI})\end{array}$} & \multirow{3}{*}{$\begin{array}{l}\mathrm{p}- \\
\text { value }\end{array}$} \\
\hline \multirow[t]{2}{*}{ BMI } & \multicolumn{2}{|c|}{ normal } & \multicolumn{2}{|c|}{ Abnormal } & \multicolumn{2}{|c|}{ Total } & & \\
\hline & $\mathrm{N}$ & $\%$ & $\mathrm{n}$ & $\%$ & $\mathrm{n}$ & $\%$ & & \\
\hline Normal & 15 & 48.4 & 16 & 54.6 & 31 & 100 & \multirow{4}{*}{$\begin{array}{c}0.547 \\
(0.17- \\
1.76)\end{array}$} & \multirow{4}{*}{0.309} \\
\hline Tidak & & & & & & & & \\
\hline Normal & 12 & 63.2 & 7 & 36.8 & 19 & 100 & & \\
\hline Total & 27 & 54 & 23 & 46 & 50 & 100 & & \\
\hline
\end{tabular}

From Table 6 it can be seen that there are $16(54.6 \%)$ respondents with normal Body Mass Index (BMI) who have abnormal bone mineral density. Meanwhile, among respondents with an abnormal body mass index (BMI), 7 (36.8\%) had abnormal bone mineral density.

The results of the chi-square test with a confidence level of $95 \%(\alpha=0.05)$ showed that there was no significant relationship between the Body Mass Index (BMI) of respondents with normal bone mineral density and respondents with abnormal bone mineral density $(\mathrm{p}=0.309)$.

\section{IV.DISCUSSION}

Calcium $(\mathrm{Ca})$ is one of several minerals that play a role in bone formation and as much as $99 \%$ of the calcium in the body is in the bones. Early in life, adequate calcium intake can optimize peak bone density and in later life can prevent bone loss. Low calcium intake affects the initial bone density so that it can affect subsequent growth and accelerated bone loss [15]. Calcium is a specific nutrient that is most important for the attainment of peak bone mass, prevention and treatment of osteoporosis. The increase in calcium consumed contributes to maximizing the attainment of peak bone mass and protects against bone loss. During the growth period, calcium deficiency causes a reduction in the mass and hardness of the bone formed [16]. The results of this study were in line with the results of research by Setyawati [17]which stated that there was a significant relationship between calcium intake and bone mineral density $(\mathrm{p}<0.05)$. Calcium intake $<500 \mathrm{mg}$ / day has twice the risk of experiencing low DMT compared to adequate calcium intake.
Osteoporosis is defined as a bone mineral density (BMD) that is more than $-2.5 \mathrm{SD}$ below average. The peak achievement of BMD is related to calcium intake and physical exercise [18].

Body mass index is one of the factors that influence osteoporosis. Low body mass index is a risk factor for osteoporotic fracture. This risk was evident in people with a body mass index $<20 \mathrm{~kg} / \mathrm{m} 2$. A high body mass index is associated with high bone mass and a reduction in body mass can lead to a reduction in bone mass [19].

The reduction in bone mass associated with osteoporosis is characterized by an increased risk of skeletal and non- skeletal fractures, persistent pain and decreased function, which has side effects on quality of life [20].

Bone mineral density values are influenced by the attainment of peak bone mass and the amount of bone lost with increasing age. The attainment of peak bone mass and optimal bone strength from an early age that is maintained during young adulthood plays an important role in preventing osteoporosis and fractures in the future [21].

The results of this research indicated that Body Mass Index (BMI) of respondents did not significantly correlate with the bone mineral density. The results of this study are also similar to Humaryanto's [22]research that there was no significant relationship between Body Mass Index (BMI) and bone mineral density.The insignificant relationship between Body Mass Index (BMI) and bone mineral density in this study is because respondents who have normal and abnormal Body Mass Index (BMI) are almost the same and the range is not too wide besides that BMI cannot accurately describe the condition of the respondent's frame because BMI cannot distinguish the body composition of the respondents whether it is predominantly fat or muscle mass.

\section{CONCLUSION}

There is a relationship between calcium intake and density and there is no relationship between Body Mass Index (BMI) and bone density. It is suggested to collaborate with the health team, especially nutritionists to provide education about bone density and the benefits of calcium sources in maintaining bone density and routine bone density checks which can be used as early detection to prevent osteopenia.

\section{VI.ACKNOWLEDGMENT}

The author is grateful to Health Polytechnic Palembang. 


\section{REFERENCES}

[1] Anderson JJ. No Title. L kathleen. Philadelpia: Saunders company; 2000.

[2] Muda WD. 3hqjhwdkxdq 7hqwdqj 2vwhrsrurvlv«\%xgl 6 1ryldwl 6dolpdu 2014:1-10.

[3] Borges JLC, Brandão CMA. Low bone mass in children and adolescents. Arq Bras Endocrinol Metabol 2006;50:775-82. https://doi.org/10.1590/S000427302006000400022

[4] Branca. No Title. Rome,Italy: 1997.

[5] Depkes.R.I. No Title. Jakarta: Litbangkes; 2002.

[6] Ensrud. No Title. 2007.

[7] Kakap I, Lutjanus M, Pengaruh K, Tepung S, Dengan I, Maggot T, et al. Daftar Pustaka 2012:39-40.

[8] Hardinsyah H, Damayanthi E, Zulianti W. Hubungan Konsumsi Susu Dan Kalsium Dengan Densitas Tulang Dan Tinggi Badan Remaja. J Gizi Dan Pangan 2008;3:43. https://doi.org/10.25182/jgp.2008.3.1.43- 48.

[9] Harvey, Choper. Gizi Kesehatan Masyarakat 2013;50:1115.

[10] Thompson J, Manore M, Vaughan L. The Science of Nutrition, 2nd Edition. 2011.

[11] Fikawati S, Syafiq A, Nurjuaida S. Pengaruh suplementasi zat besi satu dan dua kali per minggu terhadap kadar hemoglobin pada siswi yang menderita anemia. Universa Med 2016;24:167-74.

[12] Muliadi D. Universitas Sumatera Utara 7 2015:7-37.

[13] Menkes RI. No Title. 2008.

[14] Prihartini s. No Title. 2010.

[15] Reginter JY. No Title. Bone J 20005:Osteoprosis a still increasing prevalence.

[16] Sankaran. No Title. Mumbai: South EAst Asia Ragion Office of the world health Organizer; 2000.

[17] Setyawati B JE. dan AD. No Title. Penelit Gizi Dan Makanan 2013:Faktor yang berhubungan dengan densitas mineral tu.

[18] Shroff M and Pai B. No Title. Megazine India: 2000.

[19] Soekatri M Kartono D. No Title. Jakarta: 2004.

[20] Suryono. No Title. Life Pangan 2007:pengaruh pemberian susu terhadap Indeks Massa tubu.

[21] Tandra H. No Title. Jakarta: 2009

[22] Tusmantoyo. No Title. Jember: 2014. 